\title{
Development of the Tourism Industry as the Motor of Economic Growth in Indonesia
}

\author{
Dyah Poespita Ernawati \\ Institut Pemerintahan Dalam Negeri (IPDN), Indonesia \\ Email: dyah.poespita1968@gmail.com
}

\begin{abstract}
The tourism sector is one of the activities that have a strategic role in supporting international economic development in the era of globalization influencing the development of the tourism industry for the development of areas around tourist objects so that they can act as a leading industry, sectors that can improve the economy. The existence of the tourism sector will create jobs that will increase the income of people in tourist areas. When linked to economic development with balanced growth, tourism can be expected to play a decisive role and be a catalyst for developing its development sector. Meanwhile, the economic impact of tourism development can be positive or negative. The positive effects are (1) creating jobs, (2) increasing opportunities, (3) increasing community income in the surrounding tourist areas. Meanwhile, the environment's negative impact is the natural environment, the built environment, and culture.
\end{abstract}

Keywords: Tourism Industry, Economic Growth, Employment, Income.

\section{A. INTRODUCTION}

To encourage the level of community welfare, the government needs to make strategic efforts to improve its people's welfare (Lewis, 1992). Tourism is one of the sectors expected to make a significant contribution to maintain economic stability and increase the community's interest (Crouch \& Ritchie, 1999). Therefore, tourism development needs to be continued and enhanced by using tourism resources and the potential to become an economic and non-economic force that can be relied on in supporting the national economy (Frederick, 1993).

In its development, tourism today has a strategic role in economic growth in various countries. Many countries continue to take tourism potential seriously and make tourism a leading sector in foreign exchange earnings, job creation and poverty alleviation, increasing income, living standards, and stimulating other production factors (Ayres, 2000). Therefore, various businesses have emerged that impact expanding the economy in a tourism area, such as hotels, inns, travel agencies, restaurants, the handicraft industry, art shops, and various other supporting facilities (Frederick, 1993). As for tourism with its various positive aspects, it is seen as a passport to development, new kind of sugar, tools for regional development, invisible export, non-polluting industry, and so on (Muhanna, 2006). However, it is not uncommon for tourism to be treated only as an ordinary industry; of course, it has implications for developing tourism education which emphasizes learning on the technical know-how aspect. Simultaneously, the know-what and 
know-why sides are still relatively underdeveloped and underdeveloped (HigginsDesbiolles, 2006).

The tourism sector has tremendous and effective potential to break Indonesia's foreign exchange through a tourism development strategy planned and carried out by the culture and tourism office (Hairurrozi, 2019). The tourism sector's contribution is the largest in economic development, so that the progress of tourism must be maximally supported to generate significant economic growth (Dwyer et al., 2009). The development of the tourism sector does not only include natural resources. Still, it must be accompanied by human resources, and the area of the area can accommodate a vast number of tourist visitors (Navickas \& Malakauskaite, 2009).

In reality, Indonesia's tourism development continues to develop and is an essential factor in supporting its economy (Nizar, 2011). This development is because Indonesian tourism has such an enormous tourism potential that it can attract investors to invest (invest) and develop the tourism potential that is already available (Setiawan, 2016). On the other hand, tourism can also function to bring the Indonesian people's name or image to be known internationally. As one of the development sectors that can spur economic growth, tourism is perceived to be a strategic tool to promote growth of many regions with future tourist attractions (Yakup, 2019).

The World Travel \& Tourism Council (WTTC) stated that the tourism industry's potential convinced the government to encourage the advancement of the number of foreign tourists who came on tour by improving adequate facilities to enjoy the beauty of all tourist destinations (Zuhro, 2019). The growth of Indonesian tourists was recorded as the 9th highest in the world. President Joko Widodo stated that Indonesia had entered the top 10 countries that must be visited because it is the sixth most beautiful country globally. Thus the president ordered the House of Representatives to commit to developing the tourism sector as an industrial sector that contributes to economic growth (Zuhro, 2019).

The tourism sector's existence should support all parties such as the government as a manager, group on the position of tourist items and the participation of the private sector as a tourism developer and manager (Sutawa, 2012). Economically, tourism will benefit investors, organizers and directly improve the welfare of the people around them (Scerri et al., 2019). Apart from its role, tourism is also a sector that is not much different from other economic sectors, namely in its development; it also has an impact or influence in the social and economic fields of society. The effect can be in the form of a positive or negative influence on the local community's life (Pramono, 1993). To prevent this change from going in a negative direction, planning is needed that includes various aspects, mainly social and economic aspects, so that as far as possible, the local community is involved in tourism planning and development (Safriana, 2018).

In principle, the development and development process of a region in Indonesia can be supported by its tourism potential. Based on statistical data, it is 
noted that the tourism sector provides a sizeable contribution to the national economy. The number of international visitor visits (tourists) to Indonesia reached 1.41 million trips in December 2018, an increase of 22.54 per cent relative to the number of foreign tourists visiting Indonesia in December 2017, which was 1.15 million. Likewise, relative to November 2018, the number of international visitor visits rose by 21,43\% in December 2018 (BPS, 2019). The tourism potential that is owned still allows opportunities to increase state revenue from the tourism sector.

Nevertheless, the tourism industry is very vulnerable to natural environmental conditions, stability and other global facets (Ritchie, 2004). For example, the issue of terrorism, realistic damage, and the world economic crisis that has occurred have disturbed the development of Indonesia's tourism economy. Besides, the limited support for facilities and infrastructure in supporting tourism activities has resulted in not maximizing the development of Indonesia's tourism economy (Wardana, 2015). Problems also occur in the management pattern of tourism areas that are not comprehensive; this has caused negative impacts which have resulted in decreased attractiveness of tourism objects, for example, environmental damage, increased urbanization to tourist sites that have increased social problems, including increased crime and uncontrolled informal sector activities (Haryanto, 2019).

Based on the description above, this paper's problems can be formulated as follows: 1) How is economic development through the tourism sector ?; 2) To what extent is the impact of tourism development on the economy?

\section{B. METHOD}

The approach used in this research is descriptive analysis with a qualitative approach. The qualitative approach is used to formulate symptoms, information, or statements regarding economic development through the tourism sector. Thus in this study, the researcher wants to describe a reality regarding the development of the tourism economy. The most appropriate type of research is the type of qualitative analysis descriptive method, where the data is more in the form of words. The data collection methodology is based on evaluation, interview and recording, while the data processing technique is based on data collection, data reduction, data presentation and verification/conclusion.

According to Prof. Dr. Sugiyono, The qualitative analysis approach is considered a modern method; because of its recent success, it is called a postpositivist method because it is based on postpositivist. This approach is often called an artistic method since the study methodology is more of an artistic form (less patterned) and is called an interpretive method because the research data is more concerned with the interpretation of the field data (Sugiyono, 2011). Meanwhile, according to Poerwandari, qualitative research produces and processes descriptive data, such as interview transcriptions, field notes, pictures, photos or video recordings, etc. The goal of qualitative analysis is to obtain a general interpretation of social life from the viewpoint of the researchers. This interpretation 
is not defined in advance, but is extracted from an analysis of the social realities that rely on research. On the basis of this study, assumptions are taken in the context of an abstract general interpretation of reality.

\section{RESULT AND DISCUSSION}

In general, tourism is a trip that a person takes temporarily from one place to another by leaving the original site and with a plan or not to make a living in the position he is visiting, but solely to enjoy leisure or recreational activities. To fulfill various desires (Kachniewska, 2013). Tourism is a term given when a tourist travels itself or, in other words, the activities and events that occur when a visitor takes a trip. Tourism can briefly be formulated as an activity in society related to tourists (Yu et al., 2012).

According to Pitana (1989), tourism is a conscious human activity that receives services alternately between people within a country or abroad (including the occupancy of people from other areas) to seek diverse and different satisfaction. With what happened where he got a permanent job.

Meanwhile, according to Utama (2017), it explains that tourism is a trip that people take for a while, which is organized from one place to another, leaving its original position, with a plan and with the intention not to try or earn a living in the area visited. Still, only the eye to indulge in social and recreational activities or to fulfill various desires. Meanwhile, Zebua (2016) argues that tourism is an activity of traveling to get pleasure, seek satisfaction, know something, improve health, enjoy sports or resting, fulfill duties, make pilgrimages, and others. Tourism is not only a means of foreign exchange. However, it is also a factor in deciding the position of industry in the development of areas with weak natural resources, so that the production of tourism is one way to progress the economy in these underdeveloped areas as a result of a shortage of natural resources. Tourism is an indistinguishable part of human existence, particularly as regards social and economic activities. Starting from actions that a few people only enjoyed, now it has become part of human rights. This has not only arisen in developed nations, but is now starting to be felt in emerging countries. As a developing country, Indonesia is trying to build a tourism industry to achieve a balanced foreign trade balance. Through this industry, it is hoped that foreign exchange income can increase (Oppermann, 1993). As it is known, the tourism sector in Indonesia still plays a vital role in supporting national development and a very strategic factor in increasing people's income and foreign exchange.

Tourism development is a dynamic and sustainable process towards a higher value level by making adjustments and corrections based on monitoring and evaluation and feedback on the implementation of the previous plan, which is the basis of policy and is a mission that must be developed. Tourism planning and development is not a stand-alone system but is related to other development planning systems inter-sectoral and inter-regional. The current development of tourism is to increase foreign exchange and local government revenue and expand 
business opportunities in addition to providing new jobs to reduce unemployment in the regions. Tourism will increase the quality of life of people living in these tourist destinations by providing economic benefits. By developing facilities that support and provide recreational facilities, tourists and residents benefit from each other.

The development of a tourist area should show the tourist destination's cultural, historical, and economic diversity. The impact caused by tourism on the economy has two characteristics, firstly tourism products cannot be stored. Secondly, the demand is very seasonal, meaning that there is high activity in certain months, while in other months, there is little activity (low tourist season).

The tourism sector in Indonesia is one of the crucial sectors for the country's economy. In 2018, the tourism sector had a significant contribution to the country's foreign exchange, where tourism foreign exchange revenue in 2018 is estimated to reach USS 16.4 billion or an increase of 20.12 percent compared to foreign exchange earnings in 2017, which amounted to the US \$ 13.1 billion (BPS, 2019). This data shows that tourism has a role in contributing to the country's foreign exchange. This reality certainly requires development in the tourism area in Indonesia to increase foreign exchange for the country.

The development of a tourist area cannot be separated from the efforts made through the cooperation of tourism stakeholders, the community, and the government. This concept shows that tourism development in all activities and coordinated efforts to attract tourists while providing infrastructure, goods, and services, facilities needed to serve tourists' needs.

Furthermore, in increasing the potential for tourism to have economic value, it is necessary to pay attention to developing a potential tourist attraction; research, inventory and evaluation must be carried out before tourism facilities are designed. This is important so that the development of the existing tourism tank power can match the potential market demands and determine the appropriate and targeted growth.

The results show that three aspects can determine the success of tourism development as an industry; these three factors include the availability of good tourist attractions, the fulfillment of accessibility, and tourism facilities worth visiting. Besides, in the development of tourism, it is necessary to pay attention to the environment's quality so that the development of tourism does not cause a climate in which the climate's merits very much determine the tourism industry's survival. Without a good atmosphere, tourism can't develop. Therefore, tourism development must pay attention to preserving environmental quality because, in the environmental tourism industry, that is what is being sold. Tourism development in an area is determined by three factors: the availability of tourism objects and attractions, accessibility, and amenities. In building these three factors, environmental quality must be maintained.

Tourism is part of Indonesia's industrial sector, which has enormous prospects, potential, and opportunities to be developed. These opportunities are, of 
course, supported by natural conditions such as location and geographical conditions, fertile and panoramic soil layers, and a variety of flora and fauna. The purpose of developing the tourism sector is to improve the quality of life and welfare and provide benefits to the fulfillment of community needs. By setting the tourism sector, it is possible to contribute to enhancing the interest of the community.

In the implementation of economic development with balanced growth, tourism can play a decisive role. It can be used as a catalyst to develop the development of other sectors gradually. The research results show that government policies in the tourism sector directly impact, and some have an indirect effect. Apart from the above, it is possible that a government economic policy directly affects other sectors but can have an indirect impact on the tourism sector. The main objective of the government's monetary policy on tourism is to maximize tourism's contribution to the national economy. The goals of this contribution include:

1. Increase the contribution of tourism in the balance of payments

2. Expanding the quantity of employment

3. Increase and distribute people's income

4. Contribution to the improvement of social welfare

5. Optimization of fiscal revenue opportunities

Developing tourism, of course, requires a planned development as a whole so that maximum benefits can be obtained for the community both from an economic, social and cultural perspective. Such planning must integrate tourism into a country's economic, physical and social development program. Besides, the plan must provide a government policy framework in encouraging and controlling tourism development. In general, the government's role in developing tourism is to provide infrastructure, expand various facilities, coordinate activities between government officials and the private sector, regulate and promote general abroad. It is undeniable that almost all Indonesian regions have tourism potential, so what needs to be considered is the means of transportation, the state of infrastructure, and tourism facilities.

From an economic point of view, tourism can create jobs in remote areas. Compared to traditional tourism, nowadays, tourism needs relatively more significant investment to construct its facilities and infrastructure. For this reason, a careful evaluation of these natural tourism activities is necessary. Many regions in Indonesia are currently able to develop their economies through the tourism sector. On this side, the government's role is vital where tourism development automatically attracts workers and reduces unemployment. Besides, the government must be careful in seeing the tourism potentials that exist in an area.

When associated with economic development with balanced growth, tourism can be expected to play a decisive role. It can also be used as a catalyst in developing other sectors' development because not only companies can provide lodging/hotels, travel planning, food. And beverages, tour guides, but tourism also requires some 
economic infrastructure such as terminals, airports, stations, ports, sports facilities, telecommunications facilities, banks, and money changers.

The results of this study describe the existence of tourism, which can positively impact the development of other fields. However, it cannot be denied that tourism can also negatively impact people's lives, such as the circulation of illegal drugs and the entry of foreign cultures that are not following the Indonesian culture, such as free sex and drinking. Let's look at the positive impacts obtained. The tourism sector can be used as a catalyst in driving various development activities so that it can be expected to be the third source of foreign exchange after oil and gas and non-oil and gas. Within the scope of national development, the tourism sector contributes to the Gross Domestic Product (GDP), especially related to the hotel and restaurant sector.

The very rapid and concentrated development of tourism can have various impacts. In general, the impacts caused are positive impacts and negative impacts. The multiple consequences arising from tourism development can be described below:

1. Positive impact

a. The creation of various employment opportunities in the tourism sector

b. Provide additional income for people who participate in providing services to tourists who need his services.

c. The government receives income in the form of income tax and tourism company tax.

d. Encouraged development in the region in the form of repair of facilities and infrastructure in the area because the government gets revenue that can be used for inadequate facilities and infrastructure.

e. People are more eager to learn about culture and customs to be presented to tourists and make tourist objects more attractive because the cultural attractions that are served are more varied.

f. People can master several foreign languages to communicate with foreign tourists to increase their knowledge and experience.

g. Various existing resources are used optimally to foster a sense of loving the potential of our resources.

2. Negative impact

a. Negative impacts on the natural environment include natural phenomena in the surroundings.

b. Negative impacts on the built environment include cities, facilities and infrastructure, open spaces, and urban landscape elements.

c. Negative impact on the cultural environment includes values, beliefs, behavior, habits, morals, art, law, and community history.

\section{CONCLUSION}

The results of the study show that the development of the tourism industry in Indonesia, in reality, has a strong enough influence on regional development, 
especially around tourism objects, so that it can be positioned as a leading industry, namely a top sector that can improve the community's economy. Tourism can create jobs so that it boosts people's income in the tourist area. Tourism can play an essential role in determining and can be used as a catalyst for developing other sectors' development. The community feels the impact of tourism development on the economy.

As it is well known that the tourism sector has an essential role in developing the economy. This sector needs to be maximally designed to increase the people's income in the surrounding tourist areas by creating employment opportunities. Besides, there is a need for cooperation between various parties such as the government and other stakeholders to develop this tourism. The tourism sector is also expected to move the people's economy because it is considered the readiest sector in terms of facilities, facilities, and infrastructure compared to other business sectors.

\section{REFERENCES}

1. Ayres, R. (2000). Tourism as A Passport to Development in the Small States: Reflections on Cyprus. International Journal of Social Economics.

2. BPS. (2019). Jumlah Kunjungan Wisman ke Indonesia Desember 2018. https://www.bps.go.id/pressrelease/2019/02/01/1543/jumlah-kunjunganwisman-ke-indonesia-desember-2018-mencapai-1-41-juta-kunjungan.html. Accessed on 3 February 2019.

3. Crouch, G. I., \& Ritchie, J. B. (1999). Tourism, Competitiveness, and Societal Prosperity. Journal of Business Research, 44(3), 137-152.

4. Dwyer, L., Forsyth, P., \& Dwyer, W. (2009). Tourism and Economic Development Three Tools of Analysis. Tourism Recreation Research, 34(3), 307318.

5. Frederick, M. (1993). Rural Tourism and Economic Development. Economic Development Quarterly, 7(2), 215-224.

6. Hairurrozi, L. (2019). Wisata Budaya dan kesejahteraan. KOMUNITAS, 10(1), 75-94.

7. Haryanto, J. T. (2019). Kesesuaian Kegiatan Dana Alokasi Khusus (DAK) Pariwisata dan Permasalahan Pariwisata di Indonesia. Matra Pembaruan: Jurnal Inovasi Kebijakan, 3(1), 25-36.

8. Higgins-Desbiolles, F. (2006). More Than An "Industry": The Forgotten Power of Tourism As A Social Force. Tourism Management, 27(6), 1192-1208.

9. Kachniewska, M. (2013). Towards The Definition of A Tourism Cluster. Journal of Entrepreneurship, Management, and Innovation, 9(1), 33-56.

10. Lewis, J. (1992). Gender and The Development of Welfare Regimes. Journal of European Social Policy, 2(3), 159-173.

11. Muhanna, E. (2006). Sustainable Tourism Development and Environmental Management For Developing Countries. Problems and Perspectives in Management, 4(2), 14-30. 
12. Navickas, V., \& Malakauskaite, A. (2009). The possibilities for the identification and evaluation of tourism sector competitiveness factors. Engineering economics, 61(1).

13. Nizar, M. A. (2011). Pengaruh Pariwisata terhadap Pertumbuhan Ekonomi di Indonesia. Munich Personal RePEc Archive.

14. Oppermann, M. (1993). Tourism Space in Developing Countries. Annals of Tourism Research, 20(3), 535-556.

15. Pitana. (2002). Pengantar Ilmu Pariwisata. Yogyakarta: Andi.

16. Poerwandari, E. K. (2009). Pendekatan Kualitatif (Cetakan Ketiga). Depok: LPSP3 UI.

17. Pramono, H. (1993). Dampak Pembangunan Pariviisata terhadap Ekonomi, Sosial, dan, Budaya. Cakrawala Pendidikan, 78537.

18. Ritchie, B. W. (2004). Chaos, Crises, and Disasters: A Strategic Approach to Crisis Management in The Tourism Industry. Tourism Management, 25(6), 669683.

19. Safriana, R. (2018). Dampak Sosial Ekonomi Pengelolaan Pariwisata Pemerintah dan Swasta terhadap Kondisi Masyarakat Lokal (Studi Pada Obyek Wisata Small World Ketenger Baturraden Banyumas) (Doctoral dissertation, IAIN Purwokerto).

20. Scerri, M., Edwards, D., \& Foley, C. (2019). Design, Architecture and The Value to Tourism. Tourism Economics, 25(5), 695-710.

21. Setiawan, R. I. (2016). Pengembangan Sumber Daya Manusia di Bidang Pariwisata: Perspektif Potensi Wisata Daerah Berkembang. Jurnal Penelitian Manajemen Terapan (PENATARAN), 1(1), 23-35.

22. Sugiyono. (2011). Metode Penelitian Pendidikan: Pendekatan Kuantitatif, Kualitatif dan RED. Bandung: Alfabeta.

23. Sutawa, G. K. (2012). Issues on Bali Tourism Development and Community Empowerment to Support Sustainable Tourism Development. Procedia Economics and Finance, 4, 413-422.

24. Utama, I. G. B. R. (2017). Pemasaran Pariwisata. Yogyakarta: Andi.

25. Wardana, I. P. A. D., \& Sudiartha, G. M. (2015). Pengaruh Likuiditas, Ukuran Perusahaan, Risiko Bisnis Dan Usia Perusahaan Terhadap Struktur Modal Pada Industri Pariwisata DI Bursa Efek Indonesia Periode 2010-2013. E-Jurnal Manajemen, 4(6).

26. Yakup, A. P. (2019). Pengaruh Sektor Pariwisata Terhadap Pertumbuhan Ekonomi di Indonesia (Doctoral dissertation, Universitas Airlangga).

27. Zebua, M. (2016). Inspirasi Pengembangan Pariwisata Daerah. Deepublish.

28. Zuhro, F. (2019). Pengembangan Ekonomi Syariah terhadap Potensi Pariwisata Besar oleh Bank Indonesia. Islamic Banking: Jurnal Pemikiran dan Pengembangan Perbankan Syariah, 5(1), 65-80. 